University of Nebraska - Lincoln

DigitalCommons@University of Nebraska - Lincoln

USDA National Wildlife Research Center - Staff Publications
U.S. Department of Agriculture: Animal and Plant Health Inspection Service

2018

\title{
Prophage induction reduces Shiga toxin producing Escherichia coli (STEC) and Salmonella enterica on tomatoes and spinach: A model study
}

\author{
Brigitte Cadieux \\ McGill University, brigitte.cadieux@mail.mcgill.ca \\ Anna Colavecchio \\ McGill University \\ Julie Jeukens \\ Universite Laval \\ Luca Freschi \\ Universite Laval \\ Jean-Guillaume Emond-Rheault \\ Universite Laval

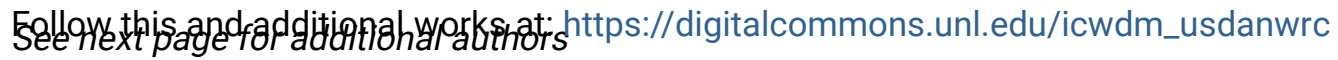 \\ Part of the Life Sciences Commons
}

Cadieux, Brigitte; Colavecchio, Anna; Jeukens, Julie; Freschi, Luca; Emond-Rheault, Jean-Guillaume; Kukavica-Ibrulj, Irena; Levesque, Roger C.; Bekal, Sakjia; Chandler, Jeffrey C.; Coleman, Shannon M.; Bisha, Bledar; and Goodridge, Lawrence D., "Prophage induction reduces Shiga toxin producing Escherichia coli (STEC) and Salmonella enterica on tomatoes and spinach: A model study" (2018). USDA National Wildlife Research Center - Staff Publications. 2079.

https://digitalcommons.unl.edu/icwdm_usdanwrc/2079

This Article is brought to you for free and open access by the U.S. Department of Agriculture: Animal and Plant Health Inspection Service at DigitalCommons@University of Nebraska - Lincoln. It has been accepted for inclusion in USDA National Wildlife Research Center - Staff Publications by an authorized administrator of DigitalCommons@University of Nebraska - Lincoln. 


\section{Authors}

Brigitte Cadieux, Anna Colavecchio, Julie Jeukens, Luca Freschi, Jean-Guillaume Emond-Rheault, Irena Kukavica-Ibrulj, Roger C. Levesque, Sakjia Bekal, Jeffrey C. Chandler, Shannon M. Coleman, Bledar Bisha, and Lawrence D. Goodridge 


\title{
Prophage induction reduces Shiga toxin producing Escherichia coli (STEC) and Salmonella enterica on tomatoes and spinach: A model study
}

\author{
Brigitte Cadieux $^{\text {a, * }}$, Anna Colavecchio ${ }^{a}$, Julie Jeukens ${ }^{b}$, Luca Freschi ${ }^{b}$, \\ Jean-Guillaume Emond-Rheault ${ }^{\mathrm{b}}$, Irena Kukavica-Ibrulj ${ }^{\mathrm{b}}$, Roger C. Levesque ${ }^{\mathrm{b}}$, \\ Sadjia Bekal ${ }^{\mathrm{c}, \mathrm{d}}$, Jeffrey C. Chandler ${ }^{\mathrm{e}}$, Shannon M. Coleman ${ }^{\mathrm{f}}$, Bledar Bisha ${ }^{\mathrm{g}}$, \\ Lawrence D. Goodridge ${ }^{\text {a }}$
}

a Department of Food Science and Agricultural Chemistry, Food Safety and Quality Program, McGill University, 21,111 Lakeshore Dr, Ste Anne de Bellevue, Québec, H9X 3V9, Canada

${ }^{\mathrm{b}}$ Institut de Biologie Intégrative et des Systèmes (IBIS), Université Laval, Québec, Québec, G1V 0A6, Canada

${ }^{c}$ Laboratoire de santé publique du Québec (LSPQ), 20045 chemin Sainte-Marie, Ste Anne de Bellevue, Québec, H9X 3R5, Canada

d Département de Microbiologie, Infectiologie et Immunologie, Université de Montréal, C.P. 6128, succ. Centre-ville, Montréal, Québec, H3C 3J7, Canada

e USDA/APHIS National Wildlife Research Center, 4101 Laporte Ave, Fort Collins, CO, 80521, USA

${ }^{\mathrm{f}}$ Department of Food Science and Human Nutrition, Iowa State University, 536 Farm House Lane, Ames, IA, 50011-1054, USA

${ }^{g}$ Department of Animal Science, University of Wyoming, 1000 E University Avenue, Laramie, WY, 82071, USA

\section{A R T I C L E I N F O}

\section{Article history:}

Available online 13 February 2018

\section{Keywords:}

Temperate bacteriophage

Prophage

Induction

Fresh produce

Foodborne pathogen

Antimicrobial

\begin{abstract}
A B S T R A C T
Fresh produce is increasingly implicated in foodborne outbreaks and most fresh produce is consumed raw, emphasizing the need to develop non-thermal methods to control foodborne pathogens. This study investigates bacterial cell lysis through induction of prophages as a novel approach to control foodborne bacterial pathogens on fresh produce. Shiga toxin producing Escherichia coli (STEC) and Salmonella enterica isolates were exposed to different prophage inducers (i.e. mitomycin C or streptonigrin) and growth of the cells was monitored by measuring the optical density $\left(\mathrm{OD}_{600}\right)$ during incubation at $37^{\circ} \mathrm{C}$. Beginning at three hours after addition of the inducer, all concentrations $(0.5,1,2 \mu \mathrm{g} / \mathrm{mL})$ of mitomycin $C$, or $2 \mu \mathrm{g} / \mathrm{mL}$ streptonigrin significantly reduced the $\mathrm{OD}_{600}$ in broth cultures, in a concentration dependent manner, relative to cultures where no inducer was added. PCR confirmed bacterial release of induced bacteriophages and demonstrated that a single compound could successfully induce multiple types of prophages. The ability of mitomycin C to induce prophages in STEC 0157:H7 and in S. enterica (serovars Typhimurium and Newport) on fresh produce was evaluated by inoculating red greenhouse tomatoes or spinach leaves with $5 \times 10^{7}$ and $5 \times 10^{8}$ colony forming units, respectively. After allowing time for the inoculum to dry on the fresh produce samples, $6 \mu \mathrm{g} / \mathrm{mL}$ mitomycin $\mathrm{C}$ was sprayed onto each sample, while control samples were sprayed with water. Following overnight incubation at $4{ }^{\circ} \mathrm{C}$, the bacterial cells were recovered and plate counts were performed. A 3 log reduction in STEC 0157:H7 cells was observed on tomatoes sprayed with mitomycin C compared to those sprayed with water, while a $1 \log$ reduction was obtained on spinach. Similarly, spraying mitomycin $C$ on tomatoes and spinach inoculated with $S$. enterica isolates resulted in a 1-1.5 log and $2 \log$ reduction, respectively. These findings serve as a proof of concept that prophage induction can effectively control bacterial foodborne pathogens on fresh produce.
\end{abstract}

(C) 2018 Elsevier Ltd. All rights reserved.

\footnotetext{
* Corresponding author.

E-mail address: brigitte.cadieux@mail.mcgill.ca (B. Cadieux).
}

\section{Introduction}

In recent years, fresh produce has been implicated in an increasing number of foodborne outbreaks involving different bacterial pathogens, including Shiga toxin producing Escherichia 
coli (STEC) and S. enterica (Bennett, Littrell, Hill, Mahovic, \& Behravesh, 2015; Callejon et al., 2015; CDC, 2011, 2013; Dechet et al., 2014; Herman, Hall, \& Gould, 2015; McCollum et al., 2013). Contamination of fresh produce can occur on the farm, pre- or postharvest, and all along the different steps of the food production chain because of inadequate hygiene, agricultural and/or manufacturing practices (EFSA, 2013, 2014). There are currently no effective means to completely remove foodborne pathogens from fresh produce during post-harvest processing steps, such as washing (Goodburn \& Wallace, 2013; Hellstrom, Kervinen, Lyly, Ahvenainen-Rantala, \& Korkeala, 2006). Furthermore, the majority of fresh produce is consumed raw, thereby eliminating the possibility of using heat to inactivate pathogens which may be present. Finally, a global trend towards eating more fruits and vegetables, as part of a healthy lifestyle, has been observed over the last thirty years (European Commission, 2007). Together, these factors contribute to an increased likelihood of contracting foodborne illnesses from eating fresh produce. Retrospective analyses of USA outbreak and epidemiological data for the period 1998-2008 indicated that $46 \%$ of illnesses were attributable to fresh produce (Painter et al., 2013) and Salmonella was the most common bacterial etiological agent (Gould et al., 2013). Analysis of Canadian outbreak data for 2001-2009 confirmed this trend and showed that Salmonella was responsible for $50 \%$ of incidents linked to fresh produce (Kozak, MacDonald, Landry, \& Farber, 2013). Since 2008, there have been at least 18 salmonellosis outbreaks linked to fresh produce in the USA (CDC, 2017). A recent and large outbreak occurred in 2015 and involved contaminated cucumbers, which resulted in 907 cases and 6 deaths (CDC, 2017).

Some antimicrobial-based strategies to control pathogens on fresh produce have been developed with varying success. The majority of reported techniques include addition of organic acids, essential oils, bacteriocins, or a combination thereof, directly on foods to inhibit bacterial growth or destroy the pathogen (Azizkhani, Elizaquivel, Sanchez, Selma, \& Aznar, 2013; Bari et al., 2005; Ganesh, Hettiarachchy, Griffis, Martin, \& Ricke, 2012; Landry, Chang, McClements, \& McLandsborough, 2014; Leverentz et al., 2003; Oliveira, Abadias, Colas-Meda, Usall, \& Vinas, 2015; Park et al., 2011). Unfortunately, these methods generally have poor efficacy and/or alter the organoleptic qualities of the food, resulting in an undesirable product for the consumer. Also, while postharvest washing, using chlorinated water, is often employed, it is not considered an intervention step, but is used instead to limit cross contamination (Gombas et al., 2017). During the past decade, bacteriophages (phages) have emerged as a new class of antimicrobials for the control of bacterial pathogens on foods. In this approach, cocktails of virulent phages are applied onto the food to control specific pathogens (Goodridge \& Bisha, 2011; Leverentz et al., 2003; Magnone, Marek, Sulakvelidze, \& Senecal, 2013; Oliveira et al., 2015; Sulakvelidze, 2013). This approach is dependent on the ability of a phage to successfully infect its bacterial host, which depends on a number of factors, including $\mathrm{pH}$ and temperature, which can limit the utility of the technology for specific foods and pathogens (J. W. Kim et al., 2012; Tsonos et al., 2014). The approach is also limited when trying to control a single diverse pathogenic species such as $S$. enterica, which contains more than 2500 serovars; as such, current commercial phage cocktails to control Salmonella are limited to only a few serovars that cause the majority of salmonellosis cases (Grant, Parveen, Schwarz, Hashem, \& Vimini, 2017; K. H.; Kim, Lee, Jang, Kim, \& Kim, 2013; Woolston et al., 2013). Also, current phage cocktails are designed to reduce a single pathogenic species or pathotype of bacteria, such as STEC, S. enterica, or Listeria monocytogenes. Given these factors, and that multiple bacterial foodborne pathogens can be associated with a single food commodity (Callejon et al., 2015; Gould et al., 2013), there is a need to design a more robust and effective antimicrobial approach which will be able to target a broader spectrum of foodborne pathogens present on fresh produce and other foods.

Genomic analyses demonstrate that most bacterial genome sequences deposited in public databases contain prophage sequences (Canchaya, Proux, Fournous, Bruttin, \& Brussow, 2003; Kang et al., 2017). This includes the presence of prophages integrated within the genomes of foodborne bacterial pathogens, such as Salmonella spp., L. monocytogenes, E. coli, Shigella spp., and Vibrio spp. (Allison \& Verma, 2000; Hayashi et al., 2001; Herold, Karch, \& Schmidt, 2004; Klumpp \& Loessner, 2013; Moreno Switt et al., 2013; Waldor \& Mekalanos, 1996). In fact, the ability of STEC to produce Shiga toxin and Vibrio cholerae to produce Cholera toxin is due to the integration of toxin encoding prophages (Brabban, Hite, \& Callaway, 2005; Gamage, Patton, Hanson, \& Weiss, 2004; Herold et al., 2004; Wagner \& Waldor, 2002; Waldor \& Mekalanos, 1996). Phages exhibit one of two lifestyles: a virulent lifestyle and a temperate lifestyle. In contrast to virulent phages, which can only grow lytically, temperate phages display lysogenic growth, meaning that once they infect their bacterial host, the phage DNA integrates into the bacterial chromosome (and becomes known as a prophage). Once integrated, prophages remain dormant until the cell experiences some form of stress, which will then induce the phages to activate their lytic cycle, replicate and lyse their host cell (Oppenheim, Kobiler, Stavans, Court, \& Adhya, 2005). Different forms of stress that have been reported to induce prophages include hydrogen peroxide, ultraviolet light, and antibiotics, such as mitomycin C and streptonigrin (Cao et al., 2012; Gerner-Smidt, Rosdahl, \& Frederiksen, 1993; Gervasi, Curto, Narbad, \& Mayer, 2013; Horgan et al., 2010; Lan et al., 2009; Levine \& Borthwick, 1963; Los, Los, Wegrzyn, \& Wegrzyn, 2010; McDonnell, 2014; Mmolawa, Willmore, Thomas, \& Heuzenroeder, 2002; Muschel \& Schmoker, 1966; Pryshliak, Hammerl, Reetz, Strauch, \& Hertwig, 2014; Wallin-Carlquist et al., 2010; Wormser \& Pardee, 1957; Yee, De Grandis, \& Gyles, 1993). In this study, cell lysis through induction of prophages was investigated as a novel approach to control bacterial pathogens on fresh produce.

\section{Materials and methods}

\subsection{Bacterial strains and growth conditions}

Strains used in this study are listed in Table 1. E. coli MC185 is a fluoroquinolone-resistant strain isolated from raccoon feces contaminating an agricultural production system, the STEC 0157:H7 strain EC920333 was isolated from a bovine source, and the Shiga toxin negative E. coli $0157: \mathrm{H7}$ strain was isolated from human feces. STEC 0157:H7 and S. enterica serovars Typhimurium and Newport were chosen because they have been previously linked to outbreaks involving fresh produce (Callejon et al., 2015; CDC, 2012, 2017; Herman et al., 2015). Specifically, the S. Newport strain used in this study was involved in an international outbreak linked to sprouted chia seed powder (Harvey et al., 2017). All strains were grown on tryptic soy agar (TSA; Becton, Dickinson and Company, Sparks, Maryland, USA) from frozen stock, followed by subculture in tryptic soy broth (TSB; Oxoid Ltd, Basingstoke, Hampshire, England), unless indicated otherwise. Ciprofloxacin $(2.5 \mu \mathrm{g} / \mathrm{mL})$ was added to overnight cultures of E. coli MC185 to promote a selective growth environment. All strains were grown at $37^{\circ} \mathrm{C}$ in an orbital shaker set at $225 \mathrm{rpm}$.

\subsection{Induction of prophages}

A $5 \mathrm{~mL}$ volume of TSB was inoculated with an overnight culture to a starting $\mathrm{OD}_{600}$ equivalent to 0.1 . The cells were grown to mid- 
Table 1

List of strains used in this study.

\begin{tabular}{lll}
\hline Taxon & Strain & Origin \\
\hline Escherichia coli & MC185 & USDA National Wildlife Research Centre \\
Escherichia coli O157:H7 & EC920333 & Health Canada \\
Escherichia coli O157:H7 - Shiga toxin negative & 43888 & American Type Culture Collection \\
Salmonella Typhimurium & LT2 & American Type Culture Collection \\
Salmonella Newport & 131174 & Laboratoire de Santé Publique du Québec \\
\hline
\end{tabular}

logarithmic phase, at which point subinhibitory concentrations of the prophage inducers, mitomycin $C(0.5-6 \mu \mathrm{g} / \mathrm{mL})$ (Sigma, St Louis, Missouri, USA) or streptonigrin $(0.25-2 \mu \mathrm{g} / \mathrm{mL})$ (Sigma), were added to the culture. Following addition of the inducers, growth of the cells was monitored over time by measuring the $\mathrm{OD}_{600}$ using a spectrophotometer (Ultrospec 100 Pro, Biochrom Ltd; Cambridge, England). To determine the number of viable cells after $20 \mathrm{~h}$ of treatment with $2 \mu \mathrm{g} / \mathrm{mL}$ mitomycin C, the cells were collected by centrifugation at $5,000 \times g$ for $10 \mathrm{~min}$ at room temperature, washed three times with phosphate-buffered saline (PBS), $\mathrm{pH} 7.5$, diluted and plated onto TSA. The resulting number of colony forming units ( $\mathrm{CFU}$ ) were counted after incubating the plates at $37^{\circ} \mathrm{C}$ for $20 \mathrm{~h}$.

\subsection{Tomato experiment}

The stem scar of fresh Beefsteak greenhouse tomatoes was inoculated with $5 \times 10^{7} \mathrm{CFU}$ of an overnight culture of the respective bacteria. After allowing time for the inoculum to dry on the tomato samples, $5 \mathrm{~mL}$ of mitomycin C ( 2 or $6 \mu \mathrm{g} / \mathrm{mL}$ ) was sprayed on the complete tomato surface, while control tomatoes were sprayed with an equal volume of water. Following overnight treatment at $4{ }^{\circ} \mathrm{C}$, the tomatoes were immersed in $25 \mathrm{~mL}$ PBS and manually agitated for $2 \mathrm{~min}$. The surviving bacterial cells were collected from the PBS by centrifugation $(15,000 \times \mathrm{g}$ for $2 \mathrm{~min})$, washed three times with PBS to remove any residual inducer, and plate counts were performed. E. coli strain MC185 was plated onto TSA $+2.5 \mu \mathrm{g} / \mathrm{mL}$ ciprofloxacin, STEC 0157:H7 was plated onto Sorbitol MacConkey Agar (Oxoid Ltd), and the Salmonella spp. strains were plated on XLT4 Agar (Fluka Analytical - Sigma).

\subsection{Spinach experiment}

A sample of five pre-washed baby spinach leaves (cultivars C2606, Escalade, and Stanton) were inoculated with a total of $5 \times 10^{8} \mathrm{CFU}$ of an overnight culture of the respective bacteria. After allowing time for the inoculum to dry on the spinach samples, $5 \mathrm{~mL}$ of mitomycin $C(6 \mu \mathrm{g} / \mathrm{mL})$ was sprayed onto the entire top surface of the spinach leaves, while an equal volume of water was sprayed onto control spinach leaves. The spinach leaves were exposed to the mitomycin $\mathrm{C}$ overnight at $4{ }^{\circ} \mathrm{C}$. The next day, $25 \mathrm{~mL}$ PBS was added to the spinach and the sample was homogenized for $2 \mathrm{~min}$ in a stomacher (Stomacher Lab-Blender 400, Seward Laboratory System, London, England). The surviving bacterial cells were counted as described for the tomatoes.

\subsection{DNA extraction}

Bacterial DNA was extracted from an overnight culture using the DNeasy Blood \& Tissue kit (Qiagen, Hilden, Germany) per the manufacturer's instructions. To extract phage DNA, the viral particles were collected from the lysates of bacterial cells exposed to the inducer for $20 \mathrm{~h}$. The lysates were prepared as previously described (Y. Zhang \& LeJeune, 2008). To remove any potentially contaminating bacterial DNA, lysates were treated with $1 \mu \mathrm{g} / \mathrm{mL}$ DNase I
(Roche Diagnostics, Indianapolis, Indiana, USA) for $30 \mathrm{~min}$ at $37^{\circ} \mathrm{C}$ and the enzyme was then inactivated by incubating the lysate at $75^{\circ} \mathrm{C}$ for $15 \mathrm{~min}$. Previous studies indicated that this approach was efficient at degrading DNA (data not shown). Following the DNAse treatment, viral particles were concentrated by adding a 1:100 (w/ vol) ratio of Amberlite IRA-900 ion-exchange resin (Acros Organics, New Jersey, USA) to the treated lysate and incubating at room temperature for $60 \mathrm{~min}$, while continuously mixing (PerezMendez, Chandler, Bisha, \& Goodridge, 2014). Phage DNA was extracted from the particles bound to the resin beads by resuspending the beads in $200 \mu \mathrm{L}$ of $0.85 \%$ saline. Following this step, the rest of the DNA extraction procedure was performed using the QIAamp MinElute Virus Spin kit (Qiagen) according to the manufacturer's instructions, where the resuspended beads were used instead of plasma or serum.

\subsection{Amplification of phage-specific genes}

PCR of prophage integrase genes was used to confirm the presence of prophages within bacterial genomes and the release of induced phages upon cell lysis. The integrase genes from phages with similarities to $\lambda$, SfII, Fels2, and P2 were amplified as previously described (Balding, Bromley, Pickup, \& Saunders, 2005) using a Peltier Thermal Cycler (PTC-100, Bio-Rad, Hercules, California, USA). After amplification, PCR products were separated using the QIAxcel automated capillary electrophoresis system with a DNA high resolution cartridge (Qiagen) following the manufacturer's instructions.

\subsection{Whole genome sequencing and bioinformatics analysis}

Whole genome sequencing was performed at the EcoGenomics Analysis Platform (IBIS, Université Laval, Québec, Canada). Initially, sequencing libraries were constructed using the KAPA Hyper Prep kit (Kapa Biosystems, Wilmington, MA, USA) per the manufacturer's instructions. Each 300-bp paired-end library was sequenced on an Illumina MiSeq instrument (Illumina technology, San Diego, CA, USA) with 30X coverage. The raw reads were assembled de novo using the A5 pipeline (Tritt, Eisen, Facciotti, \& Darling, 2012) and annotation was performed using RAST (Overbeek et al., 2014). Whole genome sequences have been deposited at DDBJ/ENA/GenBank under accession numbers NPKK00000000 for E. coli MC185 and NPIW00000000 for $S$. Newport. The whole genome sequence of S. Typhimurium strain LT2 (NC_003197.2) was retrieved from the National Center for Biotechnology Information database. Prophage regions within the bacterial genomes were identified using PHASTER (Arndt et al., 2016).

\subsection{Statistical analysis}

All experiments were independently performed in triplicate and the data are plotted as average values taken from repeat experiments \pm the standard deviation. Statistical analysis was performed using GraphPad QuickCalcs (GraphPad Software, San Diego, CA, USA). An unpaired, 2-tailed Student $t$-test was used to determine 
statistically significant differences $(\mathrm{P}<0.05)$ between the treated and control samples.

\section{Results}

3.1. Mitomycin $C$ induces prophages within E. coli resulting in cell death

The presence of two prophages, with similarities to phages $\lambda$ and SfII, was detected within E. coli MC185 by amplifying phagespecific integrase genes from the bacterial DNA (Fig. 1A). Additionally, whole genome sequence analysis revealed the presence of phages $\lambda$ and SfII, as well as two additional prophages identified as Fels2 and phi4795, in the genome of E. coli MC185. To determine whether the prophages identified in E. coli MC185 could be induced, cells were exposed to different subinhibitory concentrations of mitomycin C, a potent prophage inducer (Mmolawa et al., 2002; Yee et al., 1993). After $1.5 \mathrm{~h}$, a decrease in $\mathrm{OD}_{600}$ was already observed at some concentrations of mitomycin $C$ (i.e. $1-2 \mu \mathrm{g} / \mathrm{mL}$ ), and this decrease was more significant over time and as the subinhibitory concentration of mitomycin $C$ increased (Fig. 1B). These observations suggest successful prophage induction and potential lysis of the bacterial cell. To further support the hypothesis that cell lysis resulted from prophage induction, phage particles were isolated from the bacterial lysate after the cells had been exposed to mitomycin $C$ for $20 \mathrm{~h}$. Subsequently, the phage DNA was extracted and phage-specific integrases were amplified to confirm the presence of prophages in the bacterial lysate. Indeed, the integrases of phages $\lambda$ and SfII were identified in the purified lysate, indicating the release of these phages from the bacterial host cell upon cell lysis (Fig. 1A).

Next, the ability of mitomycin $C$ to induce prophages in STEC 0157:H7 was examined. Treatment of STEC 0157:H7 with mitomycin $C$ exhibited a decrease in $\mathrm{OD}_{600}$, which began at $3 \mathrm{~h}$ after addition of the inducing compound (Fig. 1C); a similar trend to that observed with E. coli strain MC185. The number of surviving cells after $20 \mathrm{~h}$ of exposure to mitomycin $\mathrm{C}$ was determined by measuring the CFU. Presence of mitomycin $C$ resulted in a $4 \log$ reduction in the number of cells for both $E$. coli strains compared to untreated cells, confirming that the observed decrease in $\mathrm{OD}_{600}$ was due to phage-dependent cell death (Fig. 1D). Taken together, these results demonstrate that subinhibitory concentrations of mitomycin $C$ effectively induced prophages within the different strains of $E$. coli used here, and that induction led to cell lysis and death.

\subsection{Streptonigrin also induces prophages within E. coli}

The ability of different concentrations of streptonigrin, another prophage inducer (Levine \& Borthwick, 1963; Muschel \& Schmoker, 1966), to induce prophages in E. coli was evaluated. As with mitomycin C, treatment of $E$. coli strain MC185 with streptonigrin resulted in a decrease in $\mathrm{OD}_{600}$ starting at $3 \mathrm{~h}$, which became more significant over time and with higher concentrations of the inducer (Fig. 2A). Addition of streptonigrin to cultures of STEC 0157:H7 also resulted in a significant decrease in $\mathrm{OD}_{600}$ by $3 \mathrm{~h}$ (Fig. $2 \mathrm{~B}$ ). These findings indicate that subinhibitory concentrations of streptonigrin induce prophages within the E. coli strains used in this study, which results in a decrease in cell numbers.
A

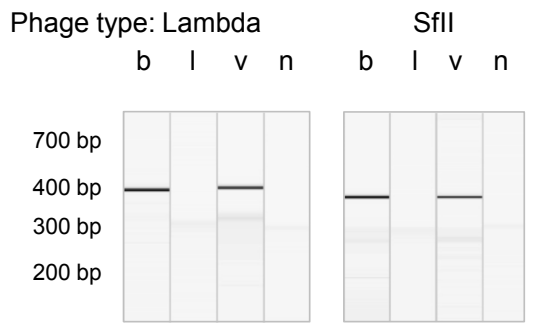

C

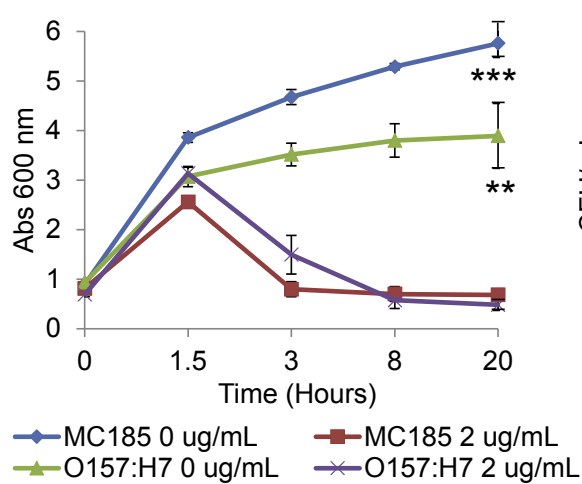

B

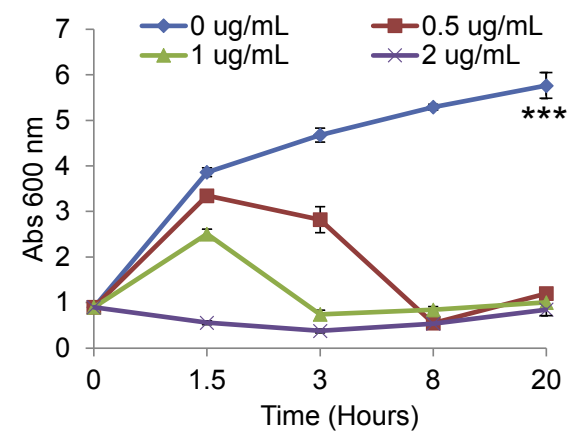

D

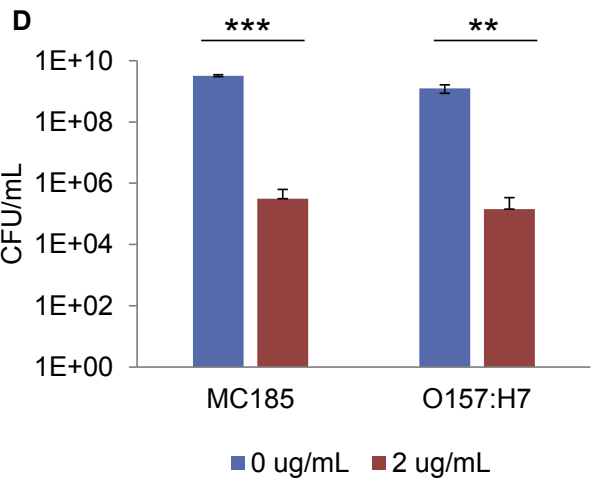

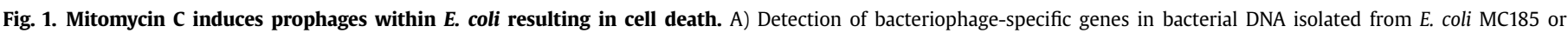

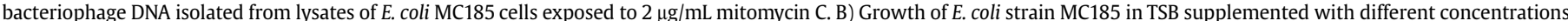

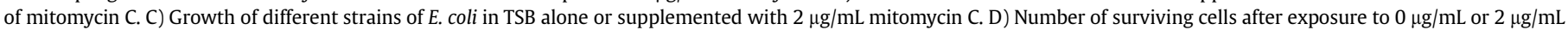
mitomycin C in TSB for $20 \mathrm{~h}$ b: bacterial DNA, l: DNAse-treated lysate, v: viral DNA, n: no DNA. Significant difference at P $<0.0001\left({ }^{* * *}\right)$, $\mathrm{P}<0.005\left({ }^{* *}\right)$. 

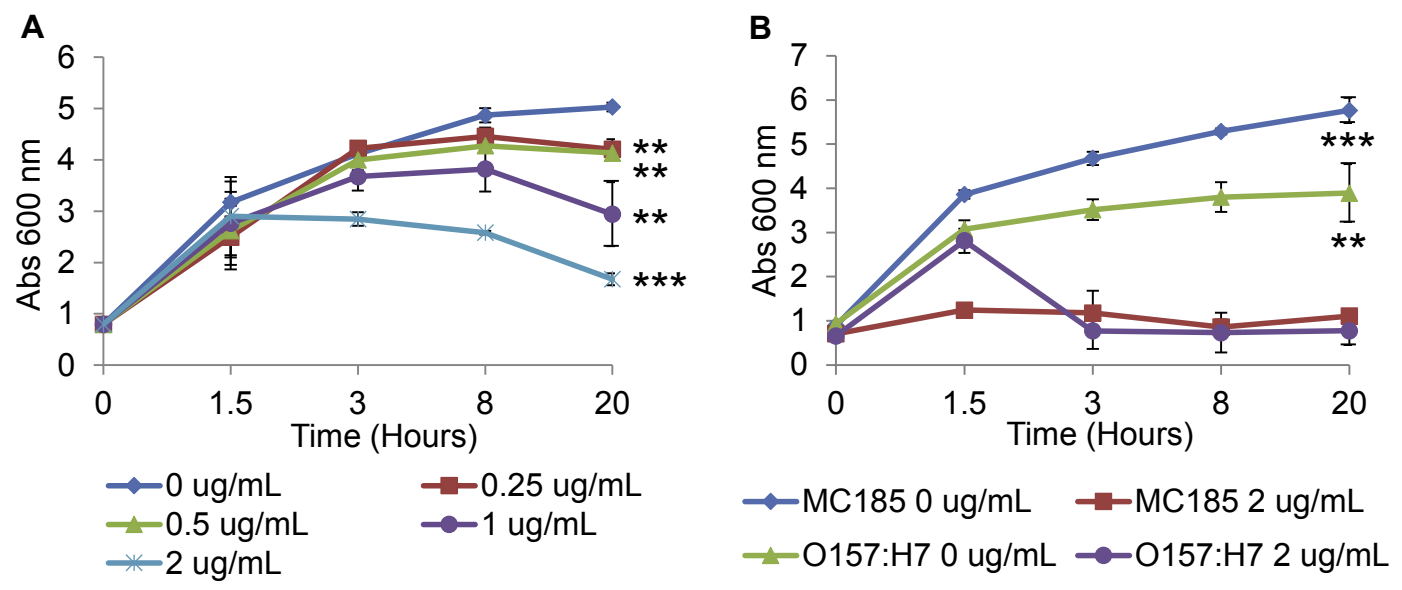

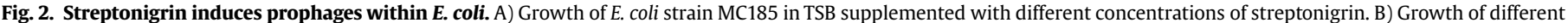
strains of $E$. coli in TSB alone or supplemented with $2 \mu \mathrm{g} / \mathrm{mL}$ streptonigrin. Significant difference at $\mathrm{P}<0.0001\left({ }^{* * *}\right)$, $\mathrm{P}<0.005\left({ }^{* *}\right)$.

\subsection{Mitomycin $C$ reduces the number of E. coli cells on fresh produce}

The next step was to determine if lysing bacterial pathogens by inducing the prophages within the cells could be used to efficiently control E. coli on tomatoes. Preliminary experiments demonstrated that $2 \mu \mathrm{g} / \mathrm{mL}$ mitomycin $\mathrm{C}$ was not sufficient to allow detection of prophage induction in $E$. coli cells inoculated onto tomatoes, while $6 \mu \mathrm{g} / \mathrm{mL}$ mitomycin $\mathrm{C}$ resulted in a detectable level of induction (Fig. 3A). Additional preliminary work, using a Shiga toxin negative E. coli $0157: \mathrm{H} 7$ isolate that did not contain inducible prophages, showed that $6 \mu \mathrm{g} / \mathrm{mL}$ mitomycin C did not inhibit growth, demonstrating that this concentration was sub-inhibitory (Fig. 3B). Consequently, a subinhibitory concentration of $6 \mu \mathrm{g} / \mathrm{mL}$ mitomycin $\mathrm{C}$ was used for the subsequent in vivo studies. Similarly to the experiments conducted in broth cultures, exposure to mitomycin $C$ significantly reduced the number of $E$. coli cells on tomatoes compared to control tomatoes sprayed with water. A $3.5 \log$ and 3 $\log$ reduction were obtained for E. coli MC185 and 0157:H7, respectively (Fig. 3C).

A similar approach was used to determine whether mitomycin $C$ could also reduce the number of $E$. coli on fresh spinach. The survival rate of $E$. coli on spinach sprayed with water was similar to that obtained on tomatoes (Fig. 3C-D). Additionally, exposure to mitomycin $C$ successfully decreased the number of surviving $E$. coli cells on spinach by $1.5 \log$ and $1 \log$ for E. coli MC185 and 0157:H7, respectively, compared to spinach sprayed with water (Fig. 3D). Together, these findings provide the proof of concept that prophage induction can effectively be used to control E. coli strains, including STEC 0157:H7, on different types of fresh produce.

\subsection{Mitomycin C induces prophages within S. enterica}

The ability of mitomycin $\mathrm{C}$ to induce prophages within Salmonella spp was also examined. Amplification of phage-specific integrase genes from the bacterial DNA of the Salmonella strains identified two prophages with similarities to phages P2 and Fels2 in $S$. Newport and S. Typhimurium, respectively (Fig. 4A). Similarly, whole genome sequence analysis revealed the presence of Fels2 and Gifsy 2 in S. Typhimurium, while Gifsy1 and Fels1 were present in the bacterial genomes of $S$. Typhimurium and $S$. Newport. Exposure of $S$. Typhimurium and $S$. Newport to mitomycin $C$ resulted in a decrease in $\mathrm{OD}_{600}$, at $1.5 \mathrm{~h}$ after addition of mitomycin $\mathrm{C}$ for cultures of $S$. Newport and $3 \mathrm{~h}$ for $S$. Typhimurium, compared to untreated cells, and $\mathrm{OD}_{600}$ values remained low beyond $20 \mathrm{~h}$, as was observed with strains of E. coli (Fig. 4B vs 1C). Furthermore, prophage induction resulted in bacterial concentrations that were more than 3 logs lower for both $S$. Typhimurium and $S$. Newport when the cells were exposed to mitomycin $\mathrm{C}$ for $20 \mathrm{~h}$, compared to untreated cells (Fig. 4C).

The presence of integrase genes of phages with similarities to P2 and Fels2 were identified in phages recovered from the $S$. Newport and S. Typhimurium lysates, respectively (Fig. 4A), suggesting that prophages were induced and lysed the bacterial host cells upon release of the phage. Together, these data confirm that subinhibitory concentrations of mitomycin $C$ successfully induced prophages found within the two different serovars of Salmonella, which lead to cell lysis and resulted in a decrease in the number of surviving cells.

\subsection{Mitomycin C reduces the concentration of S. enterica on fresh produce}

Finally, the use of mitomycin $C$ was evaluated to control different serovars of S. enterica, $S$. Typhimurium or $S$. Newport, on fresh tomatoes and spinach. In tomatoes, treatment with mitomycin $C$ resulted in a $1 \log$ reduction for $S$. Typhimurium and a 1.5 $\log$ reduction for $S$. Newport, when compared to control tomatoes sprayed with water (Fig. 4D). A 2 log reduction was observed for both $S$. enterica serotypes on spinach treated with mitomycin $C$ compared to those sprayed with water (Fig. 4E). Overall, these results demonstrate the feasibility of using prophage inducers to control Salmonella spp. on fresh produce and that this approach can target multiple foodborne pathogens with a single inducing compound.

\section{Discussion}

The current study demonstrates the feasibility of using prophage inducers as a novel approach to efficiently control bacterial pathogens on fresh produce. The success of this antimicrobial approach is dependent on the presence of prophage(s) within target bacteria. Studies of more than 11,000 bacterial genomes demonstrated that most bacterial species contain prophages, and identified the presence of multiple prophages within these genomes (Canchaya et al., 2003; Kang et al., 2017). Studies have also identified prophages within the genome of foodborne pathogens (Allison \& Verma, 2000; Hayashi et al., 2001; Herold et al., 2004; Klumpp \& Loessner, 2013; Moreno Switt et al., 2013; Waldor \& 
A

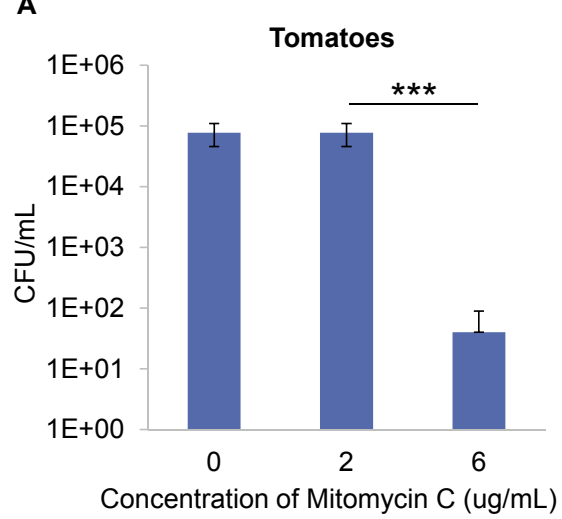

C

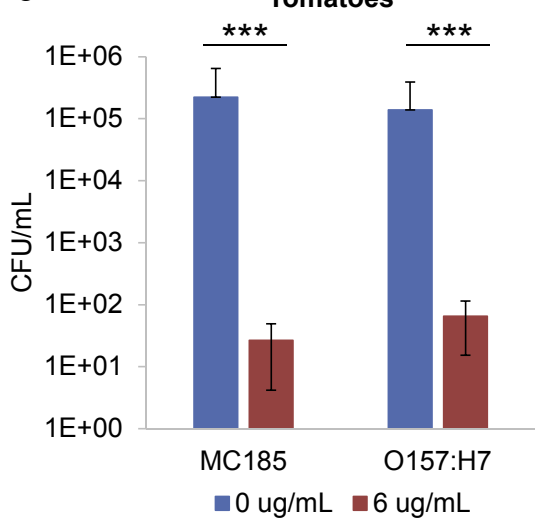

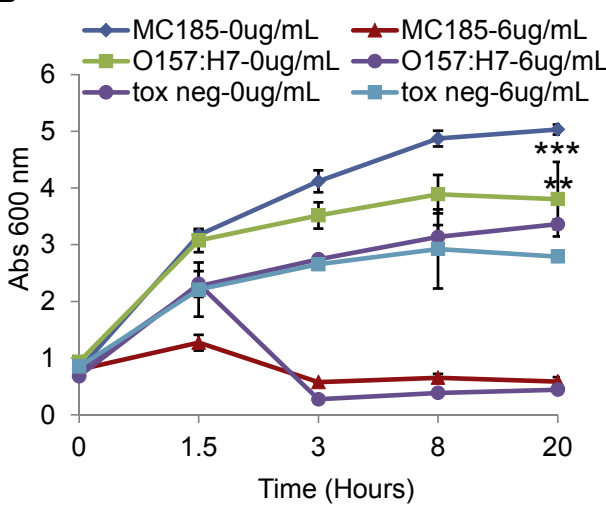

D

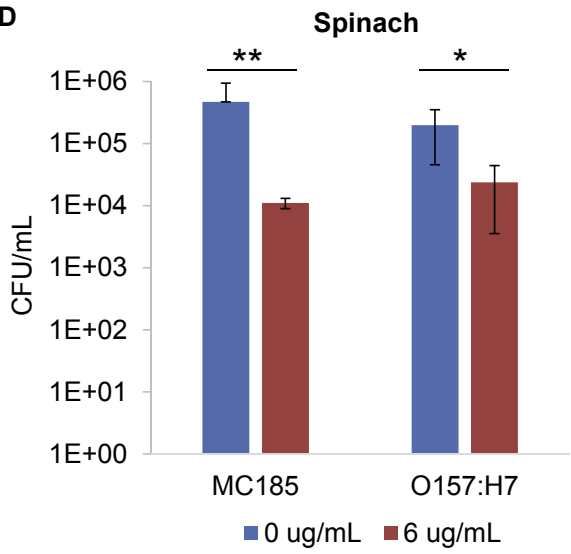

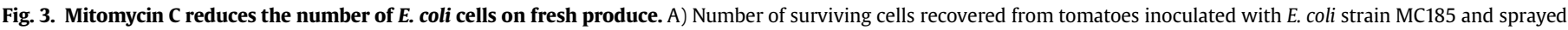

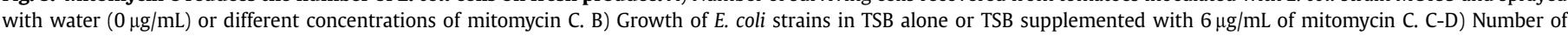

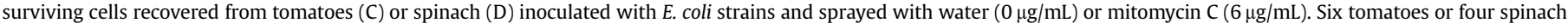

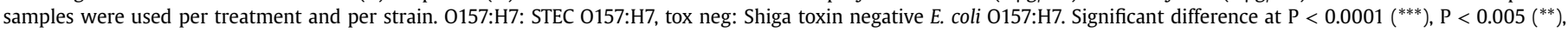
$\mathrm{P}<0.05\left(^{*}\right)$.

Mekalanos, 1996). Perhaps the most striking example of this is the STEC 0157:H7 Sakai strain, which contains 18 prophage genomic elements, representing $16 \%$ of the total bacterial genomic content (Canchaya et al., 2003). Additionally, we recently analyzed 1,355 Salmonella genomes from the Salmonella Food Syst-OMICs (SalFoS) database (https://salfos.ibis.ulaval.ca/), and determined that at least $90 \%$ of these genomes contained prophages (data not shown). Collectively, these studies support the potential of prophage induction in controlling bacterial pathogens in food.

In this study, subinhibitory concentrations of mitomycin $C$ and streptonigrin were used as inducers and were shown to effectively induce multiple prophages within $E$. coli, $S$. Typhimurium and $S$. Newport, and consequently led to cell lysis of the bacterial host. Mitomycin C, an antibiotic that inhibits DNA synthesis via intercalation and adduct formation (Iyer \& Szybalski, 1963, 1964; Tomasz \& Palom, 1997), has been reported to be a potent prophage inducer capable of inducing a wide range of phages in various foodborne bacterial pathogens including $E$. coli, S. enterica serovar Typhimurium, L. monocytogenes, Vibrio vulnificus, Vibrio parahaemolyticus, Clostridium perfringens, Clostridium difficile, and Staphylococcus aureus among others (Cao et al., 2012; Gerner-Smidt et al., 1993; Gervasi et al., 2013; Horgan et al., 2010; Lan et al., 2009; Mmolawa et al., 2002; Pryshliak et al., 2014; Wallin-Carlquist et al., 2010; Yee et al., 1993). Streptonigrin is another antibiotic shown to induce prophages in bacteria (Levine \& Borthwick, 1963; Muschel \& Schmoker, 1966). In this case, the antibiotic mechanism involves causing irreversible cleavage of nucleic acids (Cohen, Shaw, \& Craig, 1963; Miller, Laszlo, McCarty, Guild, \& Hochstein, 1967). In vitro experiments were carried out with mid-exponential phase cells to evaluate whether prophage induction would lead to growth cessation of the bacterial host, which would not have been possible if stationary phase cells were used. However, stationary phase cells were used in experiments involving fresh produce, because, Salmonella does not actively grow on fresh produce. Therefore stationary phase cells are more representative of the growth state of bacterial cells that would be naturally found on fresh produce, although lag phase cells could also be present.

We have established that spraying mitomycin $C$ on tomatoes can lead to as much as a $3.5 \mathrm{log}$ reduction of the targeted bacterial population, while a reduction of up to 2 logs was observed on spinach. Previous studies on the ability of other antimicrobial strategies to control pathogens on food have exhibited varying success (Azizkhani et al., 2013; Bari et al., 2005; Ganesh et al., 2012; Landry et al., 2014; Leverentz et al., 2003; Magnone et al., 2013; Oliveira et al., 2015; Park et al., 2011). For example, organic and inorganic acids, including malic, tartaric, lactic and phosphoric acids, sprayed electrostatically on spinach previously inoculated with STEC 0157:H7 (7.0 log CFU/mL) yielded a 1.1-4.0 log CFU/g reduction (Ganesh et al., 2012). Emulsions of essential oils derived from various plants (e.g. oregano, clove, thyme) have also been studied as potential antimicrobials. Carvacrol, the essential oil found in oregano, resulted in a 2-3 log reduction of STEC 0157:H7 
A

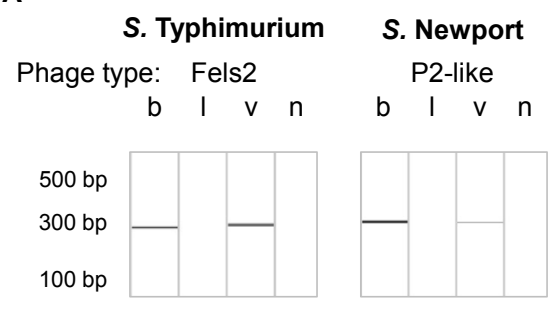

C
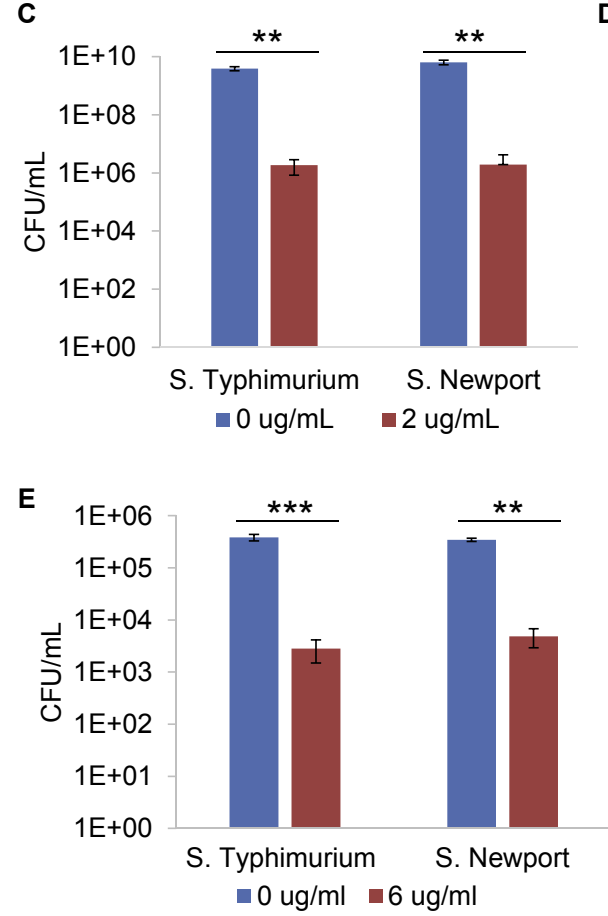

B

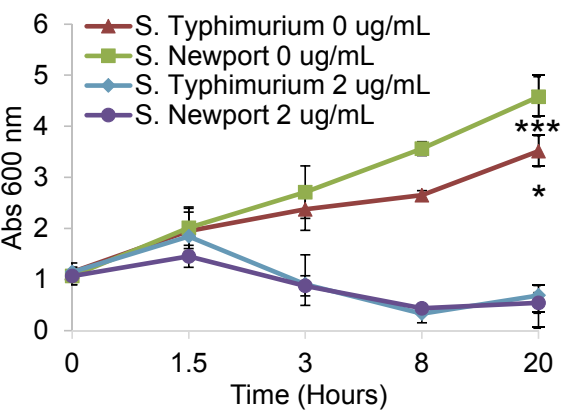

D

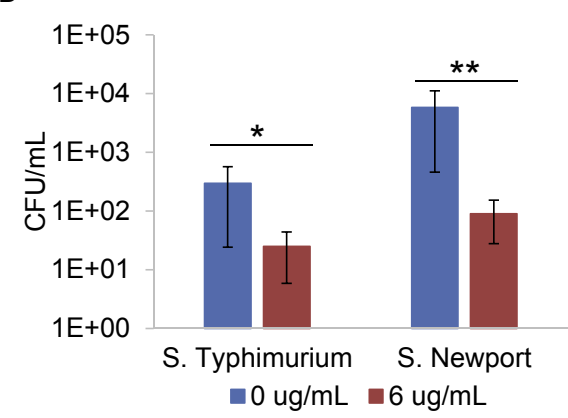

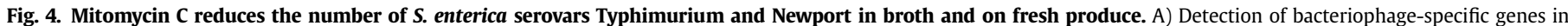

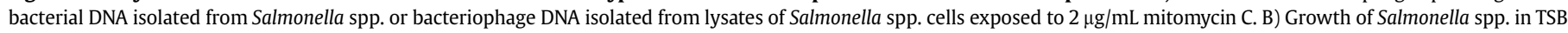

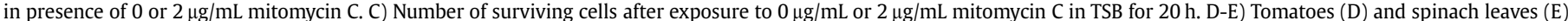

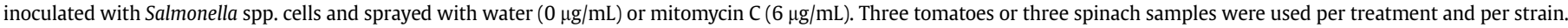
b: bacterial DNA, l: DNAse-treated lysate, v: viral DNA, n: no DNA. Significant difference at $\mathrm{P}<0.0001\left(^{* * *}\right), \mathrm{P}<0.005\left(^{* *}\right), \mathrm{P}<0.05\left(^{*}\right)$.

and $S$. Enteritidis on sprout seeds incubated at ambient temperature and a $0.5 \log$ reduction of STEC 0157:H7 on baby leaf salads stored at $7{ }^{\circ} \mathrm{C}$ (Azizkhani et al., 2013; Landry et al., 2014). Factors such as the type of antimicrobial approach used, the organism(s) targeted, the food matrix, the $\mathrm{pH}$, the temperature, the exposure time, and the concentration of the antimicrobial were all shown to influence the outcome of the challenge studies performed. The use of phages to control bacterial foodborne pathogens has previously been demonstrated by spraying virulent phage cocktails on food, including fresh produce. For example, a recent study, in which phages were used to control STEC 0157:H7 on fresh produce at $4{ }^{\circ} \mathrm{C}$ and $25^{\circ} \mathrm{C}$, reported a $2.4-3.0 \log \mathrm{CFU} / \mathrm{g}$ reduction on cut green peppers and a 3.4-3.5 log CFU/g reduction on spinach leaves (Snyder, Perry, \& Yousef, 2016). A different group examined the effectiveness of phage cocktails introduced in packaging materials to control L. monocytogenes on cantaloupes or E. coli O104:H4 on alfalfa sprouts (Lone et al., 2016). A 1-2 log reduction in the number of $L$. monocytogenes on cantaloupes and a $1 \log$ reduction of $E$. coli on germinated sprouts was observed. However, the efficacy of this type of phage-based antimicrobial method relies on successful infection of the bacterial host by the phage, which can be limited by the host range of the phage, as well as composition of the food matrix, pH, and temperature (J. W. Kim et al., 2012; Tsonos et al., 2014).

The prophage induction approach described here offers several advantages over traditional phage therapy approaches. In contrast to traditional phage-based antimicrobial approaches, the compounds used in this study, mitomycin $C$ and streptonigrin, are not reliant on phage-host interactions, and instead, cause DNA damage and initiate the SOS response in bacteria (Campoy et al., 2006). The bacterial SOS system consists of several genes aimed at guaranteeing cell survival in the presence of extensive DNA damage (Walker, 1984), and is induced by the activation of RecA after it binds to single-stranded DNA fragments (ssDNA) (Sassanfar \& Roberts, 1990). Activated RecA promotes the autocatalytic cleavage of the LexA repressor, resulting in prevention of LexA from binding to its specific recognition motif in the promoter region of SOS genes, thereby allowing the transcription of all the genes required in the SOS response (Campoy et al., 2006). In addition to the genes directly regulated by LexA, the induction of the SOS 
response, via ssDNA activation of RecA, promotes cleavage of other repressors, including lytic cycle repressors of temperate phages (Roberts \& Roberts, 1975; Sauer, Ross, \& Ptashne, 1982).

In addition, multiple studies have demonstrated the formation of bacteriophage insensitive mutants (BIMs) due to mutations in bacterial cell surface appendages used as phage receptors (Labrie, Samson, \& Moineau, 2010; O’Flynn, Ross, Fitzgerald, \& Coffey, 2004). These mutations could significantly limit the effectiveness of traditional phage-based approaches. As the SOS response is germane to bacterial survival in the presence of DNA damaging compounds and stresses (Baharoglu \& Mazel, 2014), the prophage induction approach described here would seem to target an essential cellular response, making it difficult for bacterial cells to develop resistance to this approach.

In this study, single inducing compounds, including mitomycin $\mathrm{C}$ and streptonigrin, were shown to induce at least five different prophages in E. coli and Salmonella, meaning that bacteria would potentially have to develop non-SOS based mechanisms to disrupt induction of multiple types of prophages to overcome this approach. Furthermore, as these, and related prophages, have been observed within the genomes of bacterial isolates from many bacterial species (Kang et al., 2017), a single compound could be used to simultaneously induce prophages (and therefore destroy bacteria) from multiple bacterial species. This represents an important advantage over traditional phage-based antimicrobials, which target only a single bacterial species. Further studies will be required to determine whether other inducers will effectively induce a broad range of phages. A combination of different inducers could also be used to ensure that many prophages from different bacterial species are induced. Thus, the prophage induction approach could simultaneously control multiple pathogens on foods, as well as extend the shelf life of foods by targeting several bacterial species involved in food spoilage.

As the mitomycin $C$ and streptonigrin compounds used in this study are antibiotics, and could not be used in foods due to concerns over antibiotic resistance, the results presented here represent a proof of concept that prophage induction can be an effective approach to control foodborne pathogens. Future studies will focus on the identification of natural, non-antibiotic prophage inducers. For example, hydrogen peroxide is already used as an antimicrobial to control the presence of bacterial pathogens in foods (McDonnell, 2014), and has been shown to cause DNA damage mediated prophage induction (Los et al., 2010).

One potential concern regarding the use of prophage induction as a method to reduce bacterial pathogens in foods is the possibility of horizontal transfer of virulence and antimicrobial resistance (AMR) genes from the induced prophages to other bacteria. While horizontal gene transfer due to prophage induction has received much discussion in the scientific literature, at least one recent study has called into question the frequency of temperate phage-based horizontal gene transfer (Enault et al., 2017). According to their observations, the authors concluded that the presence of AMR genes in temperate phages tends to be vastly overestimated. Recent metagenomic studies demonstrating the presence of AMR genes in temperate phages have not demonstrated transfer of these genes to other bacteria (Quiros et al., 2014). In addition, most of this work has been conducted in vitro, with few studies being conducted on prophage transduction of AMR and virulence genes in vivo. Where such studies have been conducted, temperate phage-based horizontal gene transfer generally did not occur. For example, one recent study directly examined prophage induction and horizontal gene transfer in animals. In that work, the authors used metagenomics to evaluate the effect of two antibiotics in feed (carbadox and ASP250 [chlortetracycline, sulfamethazine, and penicillin]) on swine intestinal phage metagenomes (Allen et al., 2011). They also monitored the bacterial communities using 16S rRNA gene sequencing. The authors observed that AMR genes, such as multidrug resistance efflux pumps, were identified in the phage metagenomes, but in-feed antibiotics caused no significant changes in their abundance. The abundance of phage integrase-encoding genes was significantly increased in the phage metagenomes of medicated swine over that of non-medicated swine, demonstrating the induction of prophages with antibiotic treatment. This means that while prophages were induced in the swine gut, this did not result in horizontal transfer of AMR genes from the prophages to bacteria. In another study, Cornick, Helgerson, Mai, Ritchie, and Acheson (2006) evaluated the ability of a kanamycin-marked Shiga toxin encoding phage to move into a commensal, ovine E. coli strain in the ruminant gastrointestinal tract. While transduction was detected in 19/24 samples, subtherapeutic doses of the quinolone antibiotic, enrofloxacin, did not increase the rate of transduction.

Several in vivo studies conducted in mice have demonstrated temperate phage transduction of virulence genes to bacteria. For example, subtherapeutic doses of ciprofloxacin given to streptomycin-treated mice increased the concentration of intraintestinal Shiga toxin and mortality compared to control mice, even though the viable number of STEC 0157:H7 decreased by three orders of magnitude (X. Zhang et al., 2000). In another study, an increase in phage transduction also occurred in mice inoculated with an E. coli K-12 strain carrying a kanamycin-marked Shiga toxin encoding phage and treated with subtherapeutic doses of ciprofloxacin, when compared to the transduction rate in control mice (Cornick et al., 2006). However, the pre-treatment of the mouse intestine with antibiotics, such as streptomycin, which removes a majority of the natural facultative intestinal flora, may facilitate donor-recipient cell interaction within the intestine.

These studies, when taken collectively, and combined with the fact that prophage induction occurs regularly in the animal gut (De Paepe, Leclerc, Tinsley, \& Petit, 2014), suggests that concerns regarding temperate phage-based horizontal transfer of virulence and AMR genes may be exaggerated. Additional in vivo studies will need to be conducted before definitive conclusions regarding prophage induction and horizontal gene transfer can be made.

\section{Conclusion}

The present study serves as a clear proof of concept that the prophage induction approach described here has the potential to work as a practical and effective antimicrobial technique. Such an intervention could be used in the food industry to eliminate contaminating bacterial pathogens resulting in safer fruits and vegetables for human consumption. Future studies will be required to determine if this method can be used to inactivate other foodborne bacterial pathogens which can be found in fresh produce. Moreover, the use of this novel method needs to be evaluated for its ability to control foodborne pathogens on other potentially hazardous foods, such as meat, poultry, eggs, and dairy products.

\section{Acknowledgments}

We would like to thank Yella Jovich, Sandy Tang Sik Fon and Onyinyechukwu Eberechukwu Ezearigo for technical assistance and Dr. Roger I. Cue for his help with statistical analysis. This work was supported by the United States Department of Agriculture, National Integrated Food Safety Initiative [grant number 201104858], and the National Sciences and Engineering Council of Canada Discovery Grants Program [grant number RGPIN-20140574]. 


\section{References}

Allen, H. K., Looft, T., Bayles, D. O., Humphrey, S., Levine, U. Y., Alt, D., et al. (2011). Antibiotics in feed induce prophages in swine fecal microbiomes. mBio, 2(6).

Allison, G. E., \& Verma, N. K. (2000). Serotype-converting bacteriophages and Oantigen modification in Shigella flexneri. Trends in Microbiology, 8(1), 17-23.

Arndt, D., Grant, J. R., Marcu, A., Sajed, T., Pon, A., Liang, Y., et al. (2016). PHASTER: A better, faster version of the PHAST phage search tool. Nucleic Acids Research, 44(W1), W16-W21.

Azizkhani, M., Elizaquivel, P., Sanchez, G., Selma, M. V., \& Aznar, R. (2013). Comparative efficacy of Zataria multiflora Boiss., Origanum compactum and Eugenia caryophyllus essential oils against E. coli 0157:H7, feline calicivirus and endogenous microbiota in commercial baby-leaf salads. International Journal of Food Microbiology, 166(2), 249-255.

Baharoglu, Z., \& Mazel, D. (2014). SOS, the formidable strategy of bacteria against aggressions. FEMS Microbiology Reviews, 38(6), 1126-1145.

Balding, C., Bromley, S. A., Pickup, R. W., \& Saunders, J. R. (2005). Diversity of phage integrases in enterobacteriaceae: Development of markers for environmental analysis of temperate phages. Environmental Microbiology, 7(10), 1558-1567.

Bari, M. L., Ukuku, D. O., Kawasaki, T., Inatsu, Y., Isshiki, K., \& Kawamoto, S. (2005). Combined efficacy of nisin and pediocin with sodium lactate, citric acid, phytic acid, and potassium sorbate and EDTA in reducing the Listeria monocytogenes population of inoculated fresh-cut produce. Journal of Food Protection, 68(7), $1381-1387$.

Bennett, S. D., Littrell, K. W., Hill, T. A., Mahovic, M., \& Behravesh, C. B. (2015) Multistate foodborne disease outbreaks associated with raw tomatoes, United States, 1990-2010: A recurring public health problem. Epidemiology and Infection, 143(7), 1352-1359.

Brabban, A. D., Hite, E., \& Callaway, T. R. (2005). Evolution of foodborne pathogens via temperate bacteriophage-mediated gene transfer. Foodbourne Pathogens \& Disease, 2(4), 287-303.

Callejon, R. M., Rodriguez-Naranjo, M. I., Ubeda, C., Hornedo-Ortega, R., GarciaParrilla, M. C., \& Troncoso, A. M. (2015). Reported foodborne outbreaks due to fresh produce in the United States and European Union: Trends and causes. Foodbourne Pathogens \& Disease, 12(1), 32-38.

Campoy, S., Hervas, A., Busquets, N., Erill, I., Teixido, L., \& Barbe, J. (2006). Induction of the SOS response by bacteriophage lytic development in Salmonella enterica. Virology, 351(2), 360-367.

Canchaya, C., Proux, C., Fournous, G., Bruttin, A., \& Brussow, H. (2003). Prophage genomics. Microbiology and Molecular Biology Reviews, 67(2), 238-276.

Cao, R., Zeaki, N., Wallin-Carlquist, N., Skandamis, P. N., Schelin, J., \& Radstrom, P. (2012). Elevated enterotoxin A expression and formation in Staphylococcus aureus and its association with prophage induction. Applied and Environmental Microbiology, 78(14), 4942-4948.

Centers for Disease Control \& Prevention. (2011). Multistate outbreak of listeriosis associated with Jensen Farms cantaloupe-United States, August-September 2011. MMWR Morb Mortal Wkly Rep, 60(39), 1357-1358.

Centers for Disease Control \& Prevention. (2012). Multistate outbreak of Salmonella Typhimurium and Salmonella Newport infections linked to cantaloupe (Final Update) https://www.cdc.gov/salmonella/typhimurium-cantaloupe-08-12/. (Accessed 22 August 2017).

Centers for Disease Control \& Prevention. (2013). Outbreak of Escherichia coli 0104: H4 infections associated with sprout consumption - Europe and North America, May-July 2011. MMWR Morb Mortal Wkly Rep, 62(50), 1029-1031.

Centers for Disease Control \& Prevention. (2017). Reports of selected Salmonella outbreak investigations. https://www.cdc.gov/salmonella/outbreaks.html. (Accessed 22 August 2017).

Cohen, M. M., Shaw, M. W., \& Craig, A. P. (1963). The effects of streptonigrin on cultured human leukocytes. Proceedings of the National Academy of Sciences of the United States of America, 50, 16-24.

Cornick, N. A., Helgerson, A. F., Mai, V., Ritchie, J. M., \& Acheson, D. W. (2006). In vivo transduction of an Stx-encoding phage in ruminants. Applied and Environmental Microbiology, 72(7), 5086-5088.

De Paepe, M., Leclerc, M., Tinsley, C. R., \& Petit, M. A. (2014). Bacteriophages: An underestimated role in human and animal health? Front Cell Infect Microbiol, 4, 39.

Dechet, A. M., Herman, K. M., Chen Parker, C., Taormina, P., Johanson, J., Tauxe, R. V. et al. (2014). Outbreaks caused by sprouts, United States, 1998-2010: Lessons learned and solutions needed. Foodbourne Pathogens \& Disease, 11(8), 635-644.

Enault, F., Briet, A., Bouteille, L., Roux, S., Sullivan, M. B., \& Petit, M. A. (2017). Phages rarely encode antibiotic resistance genes: A cautionary tale for virome analyses. The ISME Journal, 11(1), 237-247.

European Commission. (2007). Agricultural commodity markets past developments fruits and vegetables. An analysis of consumption, production and trade based on statistics from the Food and Agriculture Organization (FAO). Economic analyses and evaluation G.5, Agricultural trade policy analysis, European Commission Directorate-General for Agriculture and Rural Development Directorate G. 17 July 2007.

European Food Safety Authority, Panel on Biological Hazards. (2013). Scientific Opinion on the risk posed by pathogens in food of non-animal origin. Part 1 (outbreak data analysis and risk ranking of food/pathogen combinations). EFSA Journal, 11(1), 138.

European Food Safety Authority, Panel on Biological Hazards. (2014). Scientific Opinion on the risk posed by pathogens in food of non-animal origin. Part 2
(Salmonella and Norovirus in berries). EFSA Journal, 12(6), 95.

Gamage, S. D., Patton, A. K., Hanson, J. F., \& Weiss, A. A. (2004). Diversity and host range of Shiga toxin-encoding phage. Infection and Immunity, 72(12) 7131-7139.

Ganesh, V., Hettiarachchy, N. S., Griffis, C. L., Martin, E. M., \& Ricke, S. C. (2012). Electrostatic spraying of food-grade organic and inorganic acids and plant extracts to decontaminate Escherichia coli 0157:H7 on spinach and iceberg lettuce. Journal of Food Science, 77(7), M391-M396.

Gerner-Smidt, P., Rosdahl, V. T., \& Frederiksen, W. (1993). A new Danish Listeria monocytogenes phage typing system. Acta Pathologica, Microbiologica et Immunologica Scandinavica, 101(2), 160-167.

Gervasi, T., Curto, R. L., Narbad, A., \& Mayer, M. J. (2013). Complete genome sequence of PhiCP51, a temperate bacteriophage of Clostridium perfringens. Archives of Virology, 158(9), 2015-2017.

Gombas, D., Luo, Y., Brennan, J., Shergill, G., Petran, R., Walsh, R., et al. (2017). Guidelines to validate control of cross-contamination during washing of freshcut leafy vegetables. Journal of Food Protection, 80(2), 312-330.

Goodburn, C., \& Wallace, C. A. (2013). The microbiological efficacy of decontamination methodologies for fresh produce: A review. Food Control, 32(2), 418-427.

Goodridge, L. D., \& Bisha, B. (2011). Phage-based biocontrol strategies to reduce foodborne pathogens in foods. Bacteriophage, 1(3), 130-137.

Gould, L. H., Walsh, K. A., Vieira, A. R., Herman, K., Williams, I. T., Hall, A. J., et al., Centers for Disease Control \& Prevention. (2013). Surveillance for foodborne disease outbreaks - United States, 1998-2008. MMWR Surveill Summ, 62(2), $1-34$.

Grant, A., Parveen, S., Schwarz, J., Hashem, F., \& Vimini, B. (2017). Reduction of Salmonella in ground chicken using a bacteriophage. Poultry Science. https:// doi.org/10.3382/ps/pex062.

Harvey, R. R., Heiman Marshall, K. E., Burnworth, L., Hamel, M., Tataryn, J., Cutler, J., et al. (2017). International outbreak of multiple Salmonella serotype infections linked to sprouted chia seed powder - USA and Canada, 2013-2014. Epidemiology and Infection, 145(8), 1535-1544.

Hayashi, T., Makino, K., Ohnishi, M., Kurokawa, K., Ishii, K., Yokoyama, K., et al. (2001). Complete genome sequence of enterohemorrhagic Escherichia coli 0157: $\mathrm{H} 7$ and genomic comparison with a laboratory strain K-12. DNA Research, 8(1), $11-22$.

Hellstrom, S., Kervinen, R., Lyly, M., Ahvenainen-Rantala, R., \& Korkeala, H. (2006) Efficacy of disinfectants to reduce Listeria monocytogenes on precut iceberg lettuce. Journal of Food Protection, 69(7), 1565-1570.

Herman, K. M., Hall, A. J., \& Gould, L. H. (2015). Outbreaks attributed to fresh leafy vegetables, United States, 1973-2012. Epidemiology and Infection, 143(14) 3011-3021.

Herold, S., Karch, H., \& Schmidt, H. (2004). Shiga toxin-encoding bacteriophages-genomes in motion. Int J Med Microbiol, 294(2-3), 115-121.

Horgan, M., O’Sullivan, O., Coffey, A., Fitzgerald, G. F., van Sinderen, D., McAuliffe, O., et al. (2010). Genome analysis of the Clostridium difficile phage PhiCD6356, a temperate phage of the Siphoviridae family. Gene, 462(1-2), 34-43.

Iyer, V. N., \& Szybalski, W. (1963). A molecular mechanism of mitomycin action: Linking of complementary DNA strands. Proceedings of the National Academy of Sciences of the United States of America, 50, 355-362.

Iyer, V. N., \& Szybalski, W. (1964). Mitomycins and porfiromycin: Chemical mechanism of activation and cross-linking of DNA. Science, 145(3627), 55-58.

Kang, H. S., McNair, K., Cuevas, D., Bailey, B., Segall, A., \& R.A., E. (2017). Prophage genomics reveals patterns in phage genome organization and replication. bioRxiv.

Kim, J. W., Dutta, V., Elhanafi, D., Lee, S., Osborne, J. A., \& Kathariou, S. (2012) A novel restriction-modification system is responsible for temperaturedependent phage resistance in Listeria monocytogenes ECII. Applied and Environmental Microbiology, 78(6), 1995-2004.

Kim, K. H., Lee, G. Y., Jang, J. C., Kim, J. E., \& Kim, Y. Y. (2013). Evaluation of anti-SE bacteriophage as feed additives to prevent Salmonella Enteritidis (SE) in Broiler. Asian-Australasian Journal of Animal Sciences, 26(3), 386-393.

Klumpp, J., \& Loessner, M. J. (2013). Listeria phages: Genomes, evolution, and application. Bacteriophage, 3(3), e26861.

Kozak, G. K., MacDonald, D., Landry, L., \& Farber, J. M. (2013). Foodborne outbreaks in Canada linked to produce: 2001 through 2009. Journal of Food Protection, 76(1), 173-183.

Labrie, S. J., Samson, J. E., \& Moineau, S. (2010). Bacteriophage resistance mechanisms. Nature Reviews Microbiology, 8(5), 317-327.

Landry, K. S., Chang, Y., McClements, D. J., \& McLandsborough, L. (2014). Effectiveness of a novel spontaneous carvacrol nanoemulsion against Salmonella enterica Enteritidis and Escherichia coli 0157:H7 on contaminated mung bean and alfalfa seeds. International Journal of Food Microbiology, 187, 15-21.

Lan, S. F., Huang, C. H., Chang, C. H., Liao, W. C., Lin, I. H., Jian, W. N., et al. (2009) Characterization of a new plasmid-like prophage in a pandemic Vibrio parahaemolyticus 03:K6 strain. Applied and Environmental Microbiology, 75(9), 2659-2667.

Leverentz, B., Conway, W. S., Camp, M. J., Janisiewicz, W. J., Abuladze, T., Yang, M. et al. (2003). Biocontrol of Listeria monocytogenes on fresh-cut produce by treatment with lytic bacteriophages and a bacteriocin. Applied and Environmental Microbiology, 69(8), 4519-4526.

Levine, M., \& Borthwick, M. (1963). The action of streptonigrin on bacterial DNA metabolism and on induction of phage production in lysogenic bacteria. Virology, 21, 568-574.

Lone, A., Anany, H., Hakeem, M., Aguis, L., Avdjian, A. C., Bouget, M., et al. (2016). Development of prototypes of bioactive packaging materials based on 
immobilized bacteriophages for control of growth of bacterial pathogens in foods. International Journal of Food Microbiology, 217, 49-58.

Los, J. M., Los, M., Wegrzyn, A., \& Wegrzyn, G. (2010). Hydrogen peroxide-mediated induction of the Shiga toxin-converting lambdoid prophage ST2-8624 in Escherichia coli 0157:H7. FEMS Immunology and Medical Microbiology, 58(3), 322-329.

Magnone, J. P., Marek, P. J., Sulakvelidze, A., \& Senecal, A. G. (2013). Additive approach for inactivation of Escherichia coli 0157:H7, Salmonella, and Shigella spp. on contaminated fresh fruits and vegetables using bacteriophage cocktail and produce wash. Journal of Food Protection, 76(8), 1336-1341.

McCollum, J. T., Cronquist, A. B., Silk, B. J., Jackson, K. A., O'Connor, K. A., Cosgrove, S., et al. (2013). Multistate outbreak of listeriosis associated with cantaloupe. New England Journal of Medicine, 369(10), 944-953.

McDonnell, G. (2014). The use of hydrogen peroxide for disinfection and sterilization applications. In PATAI'S chemistry of functional groups (pp. 1-34). John Wiley \& Sons, Ltd.

Miller, D. S., Laszlo, J., McCarty, K. S., Guild, W. R., \& Hochstein, P. (1967). Mechanism of action of streptonigrin in leukemic cells. Cancer Research, 27(4), 632-638.

Mmolawa, P. T., Willmore, R., Thomas, C. J., \& Heuzenroeder, M. W. (2002). Temperate phages in Salmonella enterica serovar Typhimurium: Implications for epidemiology. Int J Med Microbiol, 291(8), 633-644.

Moreno Switt, A. I., Orsi, R. H., den Bakker, H. C., Vongkamjan, K., Altier, C., \& Wiedmann, M. (2013). Genomic characterization provides new insight into Salmonella phage diversity. BMC Genomics, 14, 481.

Muschel, L. H., \& Schmoker, K. (1966). Activity of mitomycin C, other antibiotics, and serum against lysogenic bacteria. Journal of Bacteriology, 92(4), 967-971.

O'Flynn, G., Ross, R. P., Fitzgerald, G. F., \& Coffey, A. (2004). Evaluation of a cocktail of three bacteriophages for biocontrol of Escherichia coli 0157:H7. Applied and Environmental Microbiology, 70(6), 3417-3424.

Oliveira, M., Abadias, M., Colas-Meda, P., Usall, J., \& Vinas, I. (2015). Biopreservative methods to control the growth of foodborne pathogens on fresh-cut lettuce. International Journal of Food Microbiology, 214, 4-11.

Oppenheim, A. B., Kobiler, O., Stavans, J., Court, D. L., \& Adhya, S. (2005). Switches in bacteriophage lambda development. Annual Review of Genetics, 39, 409-429.

Overbeek, R., Olson, R., Pusch, G. D., Olsen, G. J., Davis, J. J., Disz, T., et al. (2014). The SEED and the rapid annotation of microbial genomes using subsystems technology (RAST). Nucleic Acids Research, 42, D206-D214.

Painter, J. A., Hoekstra, R. M., Ayers, T., Tauxe, R. V., Braden, C. R., Angulo, F. J., et al. (2013). Attribution of foodborne illnesses, hospitalizations, and deaths to food commodities by using outbreak data, United States, 1998-2008. Emerging Infectious Diseases, 19(3), 407-415.

Park, S. H., Choi, M. R., Park, J. W., Park, K. H., Chung, M. S., Ryu, S., et al. (2011). Use of organic acids to inactivate Escherichia coli 0157:H7, Salmonella Typhimurium and Listeria monocytogenes on organic fresh apples and lettuce. Journal of Food Science, 76(6), M293-M298.

Perez-Mendez, A., Chandler, J. C., Bisha, B., \& Goodridge, L. D. (2014). Concentration of enteric viruses from tap water using an anion exchange resin-based method. Journal of Virological Methods, 206, 95-98.

Pryshliak, M., Hammerl, J. A., Reetz, J., Strauch, E., \& Hertwig, S. (2014). Vibrio vulnificus phage PV94 is closely related to temperate phages of $V$. cholerae and other Vibrio species. PLoS One, 9(4), e94707.
Quiros, P., Colomer-Lluch, M., Martinez-Castillo, A., Miro, E., Argente, M., Jofre, J., et al (2014). Antibiotic resistance genes in the bacteriophage DNA fraction of human fecal samples. Antimicrobial Agents and Chemotherapy, 58(1), 606-609.

Roberts, J. W., \& Roberts, C. W. (1975). Proteolytic cleavage of bacteriophage lambda repressor in induction. Proceedings of the National Academy of Sciences of the United States of America, 72(1), 147-151.

Sassanfar, M., \& Roberts, J. W. (1990). Nature of the SOS-inducing signal in Escherichia coli. The involvement of DNA replication. Journal of Molecular Biology, 212(1), 79-96.

Sauer, R. T., Ross, M. J., \& Ptashne, M. (1982). Cleavage of the lambda and P22 repressors by recA protein. Journal of Biological Chemistry, 257(8), 4458-4462.

Snyder, A. B., Perry, J. J., \& Yousef, A. E. (2016). Developing and optimizing bacteriophage treatment to control enterohemorrhagic Escherichia coli on fresh produce. International Journal of Food Microbiology, 236, 90-97.

Sulakvelidze, A. (2013). Using lytic bacteriophages to eliminate or significantly reduce contamination of food by foodborne bacterial pathogens. Journal of the Science of Food and Agriculture, 93(13), 3137-3146.

Tomasz, M., \& Palom, Y. (1997). The mitomycin bioreductive antitumor agents: Cross-linking and alkylation of DNA as the molecular basis of their activity. Pharmacology \& Therapeutics, 76(1-3), 73-87.

Tritt, A., Eisen, J. A., Facciotti, M. T., \& Darling, A. E. (2012). An integrated pipeline for de novo assembly of microbial genomes. PLoS One, 7(9), e42304.

Tsonos, J., Vandenheuvel, D., Briers, Y., De Greve, H., Hernalsteens, J. P., \& Lavigne, R. (2014). Hurdles in bacteriophage therapy: Deconstructing the parameters. Veterinary Microbiology, 171(3-4), 460-469.

Wagner, P. L., \& Waldor, M. K. (2002). Bacteriophage control of bacterial virulence. Infection and Immunity, 70(8), 3985-3993.

Waldor, M. K., \& Mekalanos, J. J. (1996). Lysogenic conversion by a filamentous phage encoding cholera toxin. Science, 272(5270), 1910-1914.

Walker, G. C. (1984). Mutagenesis and inducible responses to deoxyribonucleic acid damage in Escherichia coli. Microbiological Reviews, 48(1), 60-93.

Wallin-Carlquist, N., Cao, R., Marta, D., da Silva, A. S., Schelin, J., \& Radstrom, P. (2010). Acetic acid increases the phage-encoded enterotoxin A expression in Staphylococcus aureus. BMC Microbiology, 10, 147.

Woolston, J., Parks, A. R., Abuladze, T., Anderson, B., Li, M., Carter, C., et al. (2013). Bacteriophages lytic for Salmonella rapidly reduce Salmonella contamination on glass and stainless steel surfaces. Bacteriophage, 3(3), e25697.

Wormser, E. H., \& Pardee, A. B. (1957). Deoxyribonuclease activity in Escherichia coli K12 (lambda) after bacteriophage induction with ultraviolet irradiation. Virology, 3(1), 76-83.

Yee, A. J., De Grandis, S., \& Gyles, C. L. (1993). Mitomycin-induced synthesis of a Shiga-like toxin from enteropathogenic Escherichia coli H.I.8. Infection and Immunity, 61(10), 4510-4513.

Zhang, Y., \& LeJeune, J. T. (2008). Transduction of bla(CMY-2), tet(A), and tet(B) from Salmonella enterica subspecies enterica serovar Heidelberg to S. Typhimurium. Veterinary Microbiology, 129(3-4), 418-425.

Zhang, X., McDaniel, A. D., Wolf, L. E., Keusch, G. T., Waldor, M. K., \& Acheson, D. W. (2000). Quinolone antibiotics induce Shiga toxin-encoding bacteriophages, toxin production, and death in mice. The Journal of Infectious Diseases, 181(2), 664-670. 